\title{
Pengaruh Kompetensi Dan Perilaku Kerja Terhadap Kinerja Pemeriksa Di Inspektorat Kabupaten Bangka
}

\author{
Hattami Amar \\ Jurusan Ilmu Administrasi Negara \\ Sekolah Tinggi Ilmu Sosial Politik Pahlawan 12 Bangka \\ Hattami_amr@yahoo.com \\ Zakiyudin Fikri \\ Jurusan Ilmu Administrasi Negara \\ Sekolah Tinggi Ilmu Sosial Politik Pahlawan 12 Bangka \\ zakiyudinfikri04@gmail.com
}

\begin{abstract}
This study aimed to observe the effect of competence on the performance of Audit, behaviour in work on the performance of Audit and the influence of competence and behaviour in work on the performance of Audit in the Inspectorate of Bangka Regency. This type of research is quantitative research that is causal by using survey method. Subject and location of the study were 20 Audits in the Inspectorate of Bangka Regency. Test reliability and validitity conducted to see the validity and realibility of the research questionnaires. $F$ test is performed to determine whether independent variables simultaneously having a significant effect on the dependent variables and the $t$ test conducted to determine whether the independent variables are partially having a significant effect on the dependent variables. Statistical method of data analysis is descriptive and inferential statistics using simple and multiple regression. The results showed; there are variables influence the competence of the Audit performance in the Inspectorate of Bangka Regency of $65.2 \%$, competence is a combination of factor attitudes, knowledge and abilities. Attitude which became the dominant factor that caused the experience and education as well as by the authority of the institution. There are variables influence the behaviour in work of the Audit performance in the Inspectorate of Bangka Regency of $64,4 \%$, there are variables influence behaviour in work, spirits and excitement of work, Job involvement, power work initiative, as well as attachment to organization. Job involvement is a major supporter of behaviour in work caused by long working lives and education and structured task orders. There are variables effects competence and behaviour in work together against the Audit's performance in the Inspectorate of the Bangka Regency of 68,2\%, Competence is a very dominant factor affecting the performance of Audit in the Inspectorate of Bangka Regency.
\end{abstract}

Key words: Competence, Behaviour in Work, Audit, Performan 


\begin{abstract}
Abstrak
Penelitian ini bertujuan untuk melihat pengaruh dari kompetensi terhadap kinerja Pemeriksa, Perilaku kerja terhadap kinerja Pemeriksa dan pengaruh antara kompetensi dan Perilaku kerja terhadap kinerja Pemeriksa di Inspektorat Kabupaten Bangka. Jenis penelitian adalah penelitian kuantitatif yang bersifat kausaldengan menggunakan metode survey. Subyek dan lokasi penelitian adalah 20 orang pemeriksa di Inspektorat Kabupaten Bangka. Uji reliabilitas dan validitas dilakukan untuk melihat valid atau tidaknya kuesioner penelitian. Uji $\mathrm{F}$ dilakukan untuk mengetahui apakah variabel bebas secara simultan mempunyai pengaruh yang signifikan terhadap variabel tak bebas dan uji t dilakukan untuk mengetahui apakah variabel bebas secara parsial mempunyai pengaruh yang signifikan terhadap variabel tak bebas. Metode analisis data adalah statistik deskriptif dan statistik inferensial dengan menggunakan regresi sederhana dan regresi berganda.Hasil penelitian menunjukkan; terdapat pengaruh variabel kompetensi terhadap kinerja Pemeriksa di Inspektorat Kabupaten Bangka sebesar 65,2\%, kompetensi merupakan gabungan dari faktor sikap, pengetahuan dan kemampuan. Sikap yang menjadi faktor dominan yang disebabkan pengalaman dan pendidikan juga oleh adanya kewenangan lembaga. Terdapat pengaruh variabel perilaku kerja terhadap kinerja Pemeriksa di Inspektorat Kabupaten Bangka sebesar $64,4 \%$, perilaku kerja mencakup keterlibatan kerja, semangat dan kegairahan kerja, daya inisiatif kerja, serta keterikatan terhadap organisasi. Keterlibatan kerja merupakan pendukung utama perilaku kerja yang disebabkan oleh masa kerja yang cukup lama dan pendidikan serta adanya perintah tugas yang terstruktur. Terdapat pengaruh variabel kompetensi dan Perilaku kerja secara bersama-sama terhadap kinerja Pemeriksa di Inspektorat Kabupaten Bangka sebesar $68,2 \%$, kompetensi merupakan faktor yang berpengaruh sangat dominan terhadap kinerja pemeriksa di Inspektorat Kabupaten Bangka.
\end{abstract}

\title{
Kata kunci : Kompetensi, Perilaku kerja, Kinerja, Pemeriksa
}

\section{PENDAHULUAN}

Walker,Jdalam Iswanto,Y (2005: 5.4-5.5) menyatakankompetensi (competence), perilaku kerja (behaviour in work)merupakan variabel penting yang mempengaruhi kinerja (performance)yang dapat dikontrol oleh manajemen.Permasalahan manajemen saat iniadalah adanya jarak antara realitas dan visi kinerja tinggi, hal ini disebabkan antara lain, karyawan seringkali tidak memiliki bakat yang luar biasa menurut Walker, J dalam Iswanto, Y (2005: 5.1) dalam pengertian, orang yang biasa-biasa mengerjakan pekerjaan yang luar biasa. Oleh karena itu menjadi tugas manajemen untuk mengelola dan mengarahkan sehingga orang yang biasabiasa tersebut dapat berkinerja pada level mereka yang paling tinggi, sebab keberhasilan suatu organisasisangat ditentukan oleh kapasitas sumber daya 
manusia (kompetensi) yang meliputi; keahlian, kemampuan dan pengetahuansertaadanya tindakan dari sumber daya manusianya (perilaku) utamanya perilaku kerja, Walker, J dalam Iswanto, Y (2005: 1.45).

Satuan Kerja Perangkat Daerah (SKPD) yang menjadi objek pemeriksaan dan jumlah pemeriksa di Inspektorat Kabupaten Bangka, dengan rincian sebagai berikut:

Tabel 1.1.Jumlah objek pemeriksaan di WilayahInspektorat Kab.

Bangka

\section{No Pengelompokan SKPD(Obrik) Jumlah Obrik}

\begin{tabular}{c|lc}
1 & Bagian pada Sekretariat Pemkab Bangka & 12 \\
2 & Dinas/Badan/Kantor & 37 \\
3 & Kecamatan & 8 \\
4 & Desa dan Kelurahan & 70 \\
5 & KUPTD Pendidikaan & 8 \\
6 & Puskesmas & 11 \\
7 & Sekolah(SMP dan SMU/SMK) & 32 \\
& \multicolumn{1}{r}{ u m I a h } & 178
\end{tabular}

Sumber: Data PKPT Inspektorat Kabupaten Bangka tahun 2010/2011

Tabel 1.2. ProfilPemeriksa Inspektorat Kabupaten Bangka

\begin{tabular}{|l|c|}
\hline \multicolumn{1}{|c|}{ Uraian } & $\begin{array}{c}\text { Jumlah } \\
\text { (Orang) }\end{array}$ \\
\hline I.Tingkat Pendidikan & 1 \\
S 2 Jurusan Hukum & 1 \\
S2 Jurusan Keperawatan & 1 \\
S2 Jurusan Kepemerintahan & 1 \\
S2 Jurusan Teknik Komputer & 4 \\
S1 Jurusan Hukum & 4 \\
S1 Jurusan Ekonomi & 1 \\
S1 Jurusan Pendidikan Agama & 2 \\
Islam & 2 \\
D3 Jurusan Akuntansi & 1 \\
STM Jurusan Bangunan & 2 \\
STM Jurusan Listik & \\
SMA & 20 \\
\hline Jumlah & \\
\hline
\end{tabular}

Sumber: data kepegawaian Inspektorat Kab.Bangka tahun

$$
\text { 2011(diolah) }
$$

Dilihat dari beban tugas objek pemeriksaan (Tabel 1.1) dan jumlah pemeriksa di Inspektorat Kabupaten Bangka (Tabel 1.2), adanya kesenjangan baik dari aspek jumlah pemeriksa maupun dari aspek kualitas pemeriksa 
terhadap objek pemeriksaan. Penyebab kesenjangan adalah jumlah pemeriksa dan kualifikasi pendidikan, sebagai contoh dinas pekerjaan umum seharusnya diperiksa oleh pemeriksa yang menguasai keteknikan, terutama teknik sipil (ilmu bangunan gedung, jalan jembatan dan pengairan atau irigasi) dan Dinas Kesehatan yang memiliki spesifikasi keahlian bidang farmasi dan obat-obatan.

\section{Kerangka Teori}

\section{a.Kompetensi}

Spencer, L\& Spencer, S (1993: 9-11) menyatakan bahwa " Karakteristik kompetensi dibagi menjadi lima type yang terdiri dari: motives, traits, self concept, knowledge, dan skill. Kelima factor tersebut disebut " Iceberg Model", adapun faktor knowledge dan skill merupakan faktor yang nyata dan mudah dikembangkan. Motives, traits, dan self concept adalah faktor inti individu yang tersembunyi dan sulit untuk dikembangkan".Dharma, S (2002: 20) menyatakan bahwa:Motives merupakan suatu kondisi yang membuat seseorang bisa konsisten berfikir dengan cara siap bertindak dengan segala risikonya; Traits adalah watak yang membuat orang untuk berperilaku atau bagaimana seseorang merespon sesuatu dengan cara-cara tertentu; Self concept adalah sikap dan nilai-nilai yang dimiliki seseorang; Knowledge adalah informasi yang dimiliki seseorang untuk bidang tertentu; Skill adalah kemampuan untuk melaksanakan suatu tugas pokok tertentu baik fisik maupun mental.

Selanjutnya Definisi kompetensi semakin berkembang baik dilingkungan perusahaan yang ada didalam negeri maupun luar negeri seperti pendapat berikut, Miller, Rankin dan Neathey dalam Hutapea,P dan Thoha, N (2008: 3)berpendapat bahwa dalam lingkungan perusahaan,baik di dalam negeri maupun di luar negeri,pada awalnya hanya ada dua jenis definisi kompetensi yang berkembang pesat,yaitu:1).Kompetensi teknis atau fungsional (technical/functional competency);Kompetensi sebagai gambaran tentang apa yang harus diketahui ataudilakukan seseorang agar dapat melaksanakan pekerjaannya dengan baik;Jenis ini bermula dan berkembang di Inggris dan banyak digunakan di Negara-negara Eropa dan negera-negara Commenwealt;Konsentrasi kompetensi teknis adalah pada pekerjaan,yaitu untuk menggambarkan tanggungjawab,tantangan dan sasaran kerja yang harus dilakukanatau dicapai oleh sipemangku jabatan agar sipemangku jabatan dapat berprestasi dengan baik.2).Kompetensi perilaku (behavioural 
competencies) yang disebutdengan istilah kompetensi lunak (soft skills competency);Kompetensi yang menggambarkan bagaimana seseorang diharapkan berperilaku melaksanakan pekerjaannya.Perlu diketahui disini bahwa perilaku merupakan suatu tindakan (action) sehingga perilaku akan teridentifikasi apabila seseorang memeragakannya dalam melakukan pekerjaan.

Boyatzis dalam Hutapea,P dan Thoha,N (2008: 4), mendefinisikan kompetensi sebagai "Kapasitas yang ada pada seseorang yang bisa membuat orang tersebut mampu memenuhi apa yang disyaratkan oleh pekerjaan dalam satu organisasi, sehingga organisasi tersebut mampu mencapai hasil yang diharapkan".Woodruffe dalam Hutapea,P dan Thoha,N (2008: 4), berpendapat bahwa pengertian competence dan competency berbeda,competence diartikan sebagai konsep yang berhubungan dengan pekerjaan yang berkaitan dengan wilayah kerja dimana orang dapat menjadi kompeten atau unggul,sedangkan competency merupakan konsep dasar yang berhubungan dengan orangyang kaitannya dengan dimensi perilaku yang melandasi prestasi unggul (competency).

Spencer, L \& Spencer, S bersamaClellend, Ddalam Mangkunegara, AP (2006)berpendapat bahwaprofil kompetensi akan semakin penting bagi eksekutif, manajer dan karyawan pada perusahaan masa depan yang semakin kompetitif. Kompetensi sumber daya manusia (human resourcess) yang perlu dimiliki bagi mereka yang akan berkarir di bidang sumber daya manusia yang paling mendasar (fundamen) adalah mereka memiliki keahlian bidang manajemen sumber daya manusia,menguasai sistem manajemen informasi kepegawaian,motivasi berprestasi tinggi,kreatif,inovatif dan berkepribadian dewasa mental dengan kecerdasan emosi baik.

Usman,M(1994: 1), mengemukakan kompetensi berarti suatu hal yang menggambarkan kualifikasi atau kemampuan seseorang,baik secara kualitatif,maupun kuantitatif. Ahsan dalam Mulyasa (2003:38) mengemukakan bahwa kompetensi : "is a knowledge,skill,and abilities or capabilities that a person achieves, which become part of his or her being to the extent he or she can satisfactorily perform particular cognitive,affective, and psychomotor behaviours".Dalam hal ini kompetensi diartikan sebagai pengetahuan,ketrampilan, dan kemampuan yang dikuasai oleh seseorang yang telah menjadi bagian dari dirinya,sehingga ia dapat melakukan perilakuperilaku atas dirinya dalam aspek pengetahuan,sikap dan perlakuannya (cognitive,affective, dan psychomotoric) dengan baik. 


\section{b.Perilaku Kerja}

Dalam kehidupan bekerja,perilaku kerja merupakan bagian yang berperan sangat penting perilaku kerja merupakan tindakan dan perilaku yang ditunjukkan oleh orang-orang yang bekerja. Menurut Bond\& Meyer (1987: 40) perilaku kerja yaitu kemampuan kerja dan perilaku-perilaku dimana hal tersebut sangat penting disetiap pekerjaan atau situasi kerja.

Robbins, S (2003: 35 dan 39) menyatakan bahwa perilaku kerja adalah bagaimana orang dalam lingkungan kerja dapat mengaktualisasikan dirinya pada saat dalam bekerja. Pendapat Robbins, S ini menekankan pada umumnya diambil oleh pekerja untuk menentukan apa yang akan mereka lakukan di lingkungan tempat kerja mereka. Wathon dan Yamit (2005) menyatakan indikator perilaku kerja terdiri dari; semangat dan kegairahan Kerja, daya Inisiatif Kerja, keterlibatan Kerja, dan keterikatan terhadap Organisasi.

Keberhasilan di berbagai wilayah kehidupan ternyata juga ditentukan oleh perilaku manusia, terutama perilaku kerja. Sebagian orang menyebut perilaku kerja ini sebagai motivasi, kebiasaan (habit) dan budaya kerja. Diupayakan untuk membentuk perilaku kerja yang konsisten dan positif. Menurut Sinamo, J dan Santoso, A (2002), ada delapan paradigm ditingkat perilaku kerja yang membuahkan delapan perilaku kerja utama yang sanggup menjadi basis keberhasilan baik ditingkat pribadi, organisasional maupun sosial, yaitu : bekerja tulus, bekerja tuntas, bekerja benar, bekerja keras, bekerja serius, bekerja kreatif, bekerja unggul, dan bekerja sempurna.Indikator perilaku kerja juga dapat mengukur sampai sejauh mana perilaku kerja dapat berperan ditempat kerja.

Menurut Atmadinata, A \&Sinamo, J ( 1984 : 41 ) ada tiga macam indikator yang benar - benar mempengaruhi perilaku kerja yaitu : getting along, doing the job, dan being dependable.Indikator yang pertama Getting along (keramahtamahan), contohnya yaitu seperti hubungan antar para pekerja dan atasan, berarti bahwa suatu hubungan yang ramah dapat mempengaruhi perilaku kerja antar pekerja dan atasan. Indikator kedua yaitu Doing The Job (melakukan pekerjaan contoh: kualitas pekerjaan) yang berarti melakukan suatu pekerjaan harus dilakukan dengan baik agar dapat mengukur suatu kualitas pekerjaan yang sesuai dengan bidangnya.Dan yang ketiga yaitu Being Dependable (dapat diandalkan contohnya,ketepatan 
waktu), contoh seperti ketepatan waktu untuk masuk kerja atau menghadiri rapat.

Menurut Tsang \& Chiu ( $2000: 41$ dan 42 ) ada tiga indikator penting yang mempengaruhi perilaku kerja, yaitu:Social Behavior, Vocational Skill dan General Behavior.Indikator yang pertama adalah Social Behavior (hubungan sosial) yaitu dapat menunjukkan perilaku sosial yang sesuai dengan aturan dan norma yang ada ditempat kerja.Indikator yang kedua adalah Vocational Skill (keahlian atau kemampuan berdasarkan kejuruan). Kemampuan/pengetahuan tersebut dibutuhkan untuk melaksanakan sebuah pekerjaan, contohnya yaitu kemampuan kejuruan memasak dibutuhkan oleh seorang kokisehingga keahlian memasaknya yang sesuai dengan kejuruan yang diambil diperlukan di tempat dia bekerja.Terakhir yaitu General Behavior (perilakuumum) artinya perilaku umum yang ditunjukkan akan dapat diketahui untuk mendeteksi perilaku kerja karyawan.

\section{c. Kinerja}

Kinerja disaat ini merupakan suatu hal yang sangat penting untuk dikaji, dilihat dari definisi kinerja ternyata sangatlah beragam. Para ahli mendefinisikan kinerja dari sudut pandang yang berbeda, adapun definisiKinerja (performance),menurut Armstrong, M (1994: 1-2) sebagai berikut;(a) Kerangka kerja tujuan, standar dan persyaratan atribut/kompetensi terencana kompetensi terencana yang telah disepakati sebagai dasar darimanajemen kinerja adalah suatu kesepakatan pengelolaan akan harapan (b) .Suatu proses dari manajemen kinerja mengenai tindakan yang diambil setiap individu dalam mencapai pembebasan hasil setiap saat dalam rangka meningkatkan kinerja masing-masing termasuk orang lain;(c).Pemahaman bersama, setiap individu perlu memahami tentang tingkat kinerja dan kompetensi yang tinggi serta kearah mana tingkat kinerja tersebut akan dituju;(d).Merupakan suatu pendekatan terhadap pengelolaan dan pengembangan orang yang berfokus dari manajemen kinerja yaitu bagaimana pimpinan bekerja secara efektif bersama orang yang dipimpinnya, sebaliknya antara individu dengan rekan kerja (dalam tim) maupun antara individu dengan pemimpinnya, dan bagaimana pengembangan individu dalam rangka meningkatkan kompetensi serta kinerjanya;(e).Suatu usaha pencapaian keberhasilan organisasi dengan cara melakukan hal yang terbaik, sadar akan potensi dirinya serta berusaha memaksimalkan kontribusinya. 
Kinerja perlu ditingkatkan, melalui serangkaian usaha yang disebut dengan manajemen kinerja (performance management). Usaha dalam mengembangkan kinerja kiranya banyak faktor, elemen, unsur serta input yang ada di organisasi yang harus didayagunakan yang terkait dengan peningkatan kinerja.Dharma, S (2005: 42), berpendapat manajemen kinerja meliputi: a.Input: berupa keahlian, pengetahuan dan kepiawaian yang dibawa individu dalam melaksanakan tugas/ pekerjaannya; b. Proses: bagaimana perilaku individu dan pandangannya terhadap pelaksanaan tugas mereka; c. Output: merupakan hasil yang dicapai individu dalam melaksanakan tugas yang dapat diukur sesuai tingkatan kinerja yang dicapai; d. Outcome: merupakan dampak dari capaian kinerja individu, yang dijadikan ukuran dalam menilai efektifitas suatu pekerjaan.

Pengertian kinerja selalu beriringan antara kinerja dan sumber daya manusia menurut Mangkunegara,A (2006) berasal dari kata Job Performence atau Actual performence (prestasi kerja atau prestasi sesungguhnya yang dicapai seseorang).Definisi kinerja karyawan,yang bisa atau dapat disamakan dengan pegawai yang dikemukakan Kusriyanto,B (1991)adalah perbandingan hasil yang dicapai dengan peran serta tenaga kerja per satuan waktu (lazimnya per jam).

Gomes, Fdalam Mangkunegara,A(2006: 9) mengemukakan definisi kinerja karyawan/pegawai sebagai ungkapan seperti output,efisiensi serta efektifitas sering dihubungkan dengan produktivitas.Selanjutnya, definisi kinerja karyawan menurut Mangkunegara,A(2000:67), bahwa kinerja karyawan/pegawai(prestasi kerja) adalah hasil kerja secara kualitas dan kuantitas yang dicapai oleh seorang karyawan/pegawai dalam melaksanakan tugas sesuai dengan tanggung jawab yang diberikan kepadanya.

\section{METOdOLOGI PENELITIAN}

\section{a.waktu dan tempat penelitian}

Penelitian yang berjudul pengaruh kompetensi dan perilaku kerja terhadap kinerja pemeriksa di Inspektorat Kabupaten Bangka ini dilaksanakan pada lokus instansi pemeriksa, yaitu Inspektorat Kabupaten Bangka yang berlokasi di Jalan Pemuda Nomor 50 Kelurahan Parit Padang Kecamatan Sungailiat Kabupaten Bangka Propinsi kepulauan Bangka Belitung. Proses penelitian dijadwalkan selama 6 (enam) bulan, dimulai dari 
seminar usulan penelitian sampai sidang tesis, adapun jadwal penelitian yang dilaksanakan oleh peneliti seperti pada Tabel berikut:

Tabel.3.1 Jadwal penelitian

\begin{tabular}{|l|l|l|l|l|l|}
\hline No & Kegiatan & $\begin{array}{l}\text { Mart- } \\
\text { mei }\end{array}$ & $\begin{array}{l}\text { Jun- } \\
\text { Juli }\end{array}$ & $\begin{array}{l}\text { Agt- } \\
\text { Sept }\end{array}$ & KET \\
\hline 1. & $\begin{array}{l}\text { Tahap I Penyusunan } \\
\text { Proposal Peneltian: } \\
\text { Menyusun Proposal } \\
\text { Seminar Proposal } \\
\text { Perbaikan Proposal }\end{array}$ & $\mathrm{V}$ & & \\
& $\begin{array}{l}\text { V } \\
\text { Pahap II Penulisan Tesis: } \\
\text { Penyusunan Kuesioner } \\
\text { Analisis dan Pengolahan } \\
\text { Data } \\
\text { Penulisan laporan } \\
\text { Bimbingan tesis }\end{array}$ & & $\mathrm{V}$ & & \\
\hline 3 & $\begin{array}{l}\text { Tahap III Sidang Tesis: } \\
\text { Bimbingan Akhir tesis } \\
\text { Perbaikan tesis } \\
\text { Sidang/ujian tesis }\end{array}$ & $\mathrm{V}$ & $\mathrm{V}$ & \\
\hline
\end{tabular}

\section{b.Jenis Penelitian}

Penelitian ini merupakan penelitian kuantitatif karena peneliti berusaha mendapatkan data yang objektif, valid, dan reliabel dengan menggunakan data berbentuk angka atau data kualitatif yang diangkakan (Sugiono, 2009). Ada dua variabel bebas dalam penelitian ini yaitu Kompetensi $\left(X_{1}\right)$ dan Perilaku kerja $\left(X_{2}\right)$ serta satu variabel tak bebas yaitu Kinerja $(Y)$.

\section{c. Populasi dan Sampel}

Penelitian dilakukan pada kantor Inspektorat Kabupaten Bangka dengan objekpenelitiannya (populasi) adalah pemeriksa. Sampel merupakan sebagian atau populasi yang diteliti, populasi yang dijadikan sampel sama dengan populasi yang memuat informasi yang diperlukan, Cochran, W(1991: 6). 
Dalam penelitian ini yang menjadi sasaran (target population) adalah seluruh pemeriksa yang ada di Inspektorat Kabupaten Bangka yang berjumlah 20 (dua puluh) orang yang terdiri dari:Ketua tim pemeriksa (Inspektur Pembantu): 4 orang; Pemeriksa (Kasi Pengawas):12 orang; Pemeriksa Pembantu (Staf Pemeriksa) : 4 orang

\section{d.Instrumen Penelitian}

Instrumen yang digunakan dalam penelitian ini adalah kuesioner melalui model skala likert. Skala likert digunakan untuk mengukur sikap, pendapat, dan persepsi seseorang atau sekelompok orang tentang fenomena sosial (Sugiono, 2009: 132). Dalam skala likert, variabel yang akan diukur dijabarkan menjadi indikator. Indikator tersebut dijadikan sebagai dasar untuk menyusun item-item instrumen berupa pertanyaan atau pernyataan.Jawaban dari pertanyaan atau pernyataan tersebut diberi skor sebagai berikut:Jawaban sangat setuju sekali diberi skor 5; Jawabansangat setuju diberi skor 4; Jawaban setuju diberi skor 3; Jawaban tidak setuju diberi skor 2; Jawaban sangat tidak setujudiberi skor 1 .

\section{e. Prosedur Pengumpulan Data}

Metode pengumpulan datayang dilakukan dalam penelitian ini adalah:Studi pustaka dan Penelitian lapangan.

\section{f. Metode Analisis Data}

Analisis yang digunakan adalah Statistik diskriptif dan Statistik inferensial seperti: Uji Validitas dan Reliabilitas;Pengujian Asumsi Klasik (Uji Normalitas, Uji Heteroskedastisitas, UjiMultikolinieritas); Uji Parsial (Uji_t); Uji Simultan (Uji_F)

\section{PEMBAHASAN}

\section{1) Pengaruh kompetensi terhadapkinerja pemeriksa.}

Persamaan regresi linier sederhana dalam penelitian ini yaitu: $Y=$ $16,368+1,289 \times 1+$ e, Koefisien regresi X1 (Kompetensi) bernilai positif $(1,289)$ artinya menunjukkan kompetensi berpengaruh positif terhadap kinerja pemeriksa Inspektorat Kabupaten Bangka. Hasil penghitungan uji t dengan nilai sebagai berikut: $t$ hitung 5,803 sedangkan harga $t$ tabel pada taraf nyata 0,025 dengan derajat bebas 18 sebesar 2,10092. Dengan demikian, dapat diketahui bahwa $\mathrm{t}$ hitung lebih besar daripada $\mathrm{t}$ tabel artinya hipotesis teruji atau dengan kata lain, terdapat pengaruhvariabel kompetensi terhadap 
kinerja pemeriksa.Nilai koefisien determinasi $\left(R^{2}\right)$ sebesar 0,652 artinya besaran pengaruh kompetensi terhadap kinerja pemeriksa mencapai 65,2\%. Sebagian kecil lainnya yaitu sebesar $34,8 \%$ dipengaruhi oleh faktor-faktor lain.

Secara empirik di Inspektorat Kabupaten Bangka, faktor yang sangat berperan terhadap kompetensi pemeriksaadalah sikap, pengetahuan dan kemampuan. Penyebabnya disamping adanya pengaruh intern dari individu pemeriksa seperti pengalaman kerja dan tingkat pendidikan, juga adanya pengaruh extern seperti dengan adanya kewenangan lembaga dengan peraturan atau ketentuan yang telah ditentukan. Dengan demikian pemeriksa yang memiliki kompetensi akan lebih mudah meningkatkan kinerja yang merupakan alat/cara untuk mencapai tujuan sesuai teori yang diformulasikan oleh Walker, yaitu kinerja merupakan fungsi dari kompetensi dan perilaku kerja.

Hasil penelitian ini sejalan dengan penelitian Wahyuni (2007) yang menyatakan variabel yang signifikan menentukan kinerja pemeriksa adalah faktor kompetensi, namun berbeda dalam hal besaran pengaruh, lokasi dan indikatornya.Begitu juga hasil penelitian ini mendukung pendapat Sofo (1999) yang menyatakan kompetensi tidak hanya mengandung pengetahuan, keterampilan dan sikap, namun yang terpenting adalah penerapannya dalam pekerjaan.

\section{2) Pengaruh perilaku kerja terhadap kinerjapemeriksa.}

Persamaan regresi linier sederhana dalam penelitian ini adalah:Y= $1,620+0,974 \times 2+e$, Koefisien regresi X2 (perilaku kerja) bernilai positif $(0,974)$ artinya perilaku kerja berpengaruh positif terhadap kinerja pemeriksa di Inspektorat Kabupaten Bangka, dengan kata lain apabila semakin baik perilaku kerja pemeriksa, maka kinerja pemeriksa Inspektorat Kabupaten Bangka akan semakin meningkat.Hasil penghitungan uji $t$, nilai $t{ }_{\text {hitung }} 5,707$ sedangkan harga $\mathrm{t}$ tabel pada taraf nyata 0,025 dengan derajat bebas 18 sebesar 2,10092. Dengan demikian, dapat diketahui bahwa $t$ hitung lebih besar daripada $t_{\text {tabel }}$ artinya hipotesis teruji dan terdapat pengaruh antara variabel perilaku kerja terhadap kinerja pemeriksa.Nilai koefisiendeterminasi ( $R$ square) sebesar 0,644 , hal ini menunjukkanbahwa lebih dari sebagian(64,4\%) kinerja pemeriksa dipengaruhi oleh perilaku kerja dan sebagian kecil lainnya $(35,6 \%)$ dipengaruhi oleh faktor-faktor lain.

Pengaruh perilaku kerja terhadap kinerjapemeriksa di Inspektorat Kabupaten Bangka diukur dengan menggunakan empat faktor, yaitu: 
semangat dan kegairahan kerja, daya inisiatif kerja, keterlibatan kerja serta keterikatan terhadap organisasi ( Wathon dan Yamit: 2007). Dari hasil penelitian, faktor -faktor perilaku kerja pemeriksa yang sangat kuat mempengaruhi kinerja pemeriksa adalah keterlibatan kerja. Penyebab dari dominannya keterlibatan kerja adalah disamping faktor pengalaman dan pendidikan juga tak terlepas dari adanya factor ekstern berupa perintah tugas pemeriksaan tersebut secara terstruktur dari Bupati/wakil Bupati langsung ke Inspektorat.

Hal ini menunjukkan semangat dan kegairahan kerja yang dilaksanakan melalui disiplin, kerjasama serta adanya kepuasan bila pekerjaaan selesai tepat waktu akan sangat kuat mempengaruhi tingkat kinerja pemeriksa. Partisipasi aktif serta perilaku kerja yang mengutamakan tugas dari kepentingan pribadi akan sangat mempengaruhi kinerja pemeriksa di Inspektorat Kabupaten Bangka. Disamping itu faktor daya inisiatif kerja yang ditimbulkan oleh adanya ide atau gagasan yang cemerlang terhadap pemecahan dalam tugas serta dengan adanya tindakan cepat dengan pertimbangan yang cermat sehingga dapat meningkatkan kinerja pemeriksa di Inspektorat Kabupaten Bangka. Hubungan emosional dan kesadaran yang tinggi terhadap organisasi dimana pemeriksa merasa selalu terikat terhadap organisasi juga secara otomatis akan sangat berpengaruh terhadap kinerja pemeriksa khususnya di Inspektorat Kabupaten Bangka.

Hasil penelitian ini ada persamaan dengan penelitian yang dilakukan oleh Wathon dan Yamit (2007) yaitu sama-sama menyatakan bahwa adanya pengaruh perilaku kerja terhadap kinerja, selain itu indikator perilaku kerja yang digunakan sama yang terdiri dari semangat dan kegairahan kerja, daya inisiatif kerja, keterlibatan kerja dan keterikatan terhadap organisasi. Perbedaannya adalah dalam penentuan status variabel perilaku kerja dalam penelitian ini perilaku kerja merupakan variabel bebas sedangkan dalam penelitian mereka perilaku kerja merupakan variabel intervening.

Selanjutnya penelitian ini merujuk pendapatAtmadinata, Adan Sinamo, J (1984: 41) yang menyatakan ada empat macam indikator yang benar-benar mempengaruhi perilaku kerja adalah: getting along (keramahtamahan), doing the job (melakukan pekerjaan), dan being Dependable (dapat diandalkan).

\section{3) Pengaruhkompetensi dan perilaku kerja terhadap kinerja pemeriksa.}


Persamaan regresi berganda dalam penelitian ini adalah: $Y=10,362+$ $0.714 \times 1+0.485 X 2+e$, Koefisien regresi X1 (kompetensi) bernilai positif $(0,714)$ artinya kompetensi berpengaruh positif terhadap kinerja pemeriksa, bila kompetensi pemeriksa meningkat (sikap, pengetahuan dan kemampuan), maka kinerja pemeriksa juga akan mengalami peningkatan.Koefisien regresi X2 (perilaku kerja) bernilai positif $(0,485)$, ini menunjukkan bahwa pengaruh perilaku kerja adalahpositif terhadap kinerja pemeriksa di Inspektorat Kabupaten Bangka. Dengan demikian apabilaterjadi peningkatan perilaku kerja yang mencakupsemangat dan kegairahan kerja, daya inisiatif kerja, keterlibatan kerja serta keterikatan terhadap organisasi, maka kinerja pemeriksa Inspektorat Kabupaten Bangka juga akan semakin meningkat.

Nilai koefisien determinasi ( $R$ square) adalah sebesar 0,682 , hal ini menunjukkan bahwa variabel-variabel bebas yang diteliti yaitu kompetensi dan perilaku kerja secara bersama-sama berpengaruh 68,2\% terhadap kinerja pemeriksa. Sedangkan sisanya sebesar $31,8 \%$ disebabkan oleh faktor lainnya.

Hasil penghitungan uji $\mathrm{F}$ diperoleh nilai $\mathrm{F}_{\text {hitung }} 18,199$ sedangkan harga kritis nilai $F_{\text {tabel }}$ dengan derajat bebas pembilang 2 dan penyebut 17 pada a $(0,05) 3,590$. Dengan demikian $F_{\text {hitung }}(18,199)>F_{\text {tabel }}(3,590)$ sehingga $H_{0}$ ditolak dan $\mathrm{H}_{1}$ diterima artinya secara bersama-sama variabel kompetensi (X1) dan perilaku kerja (X2) mempunyai pengaruh terhadap kinerja pemeriksa di Inspektorat Kabupaten Bangka (Y).Hal ini juga dapat diketahui dari nilai tingkat signifikansi 0,000 ,karena probabilitas $(0,000)$ jauh lebih kecil dari 0,05. Hasil uji simultan (uji F) terhadap regresi berganda.

Dari hasil penelitian menyatakan bahwa kompetensi dan perilaku kerja secara bersama-samaberpengaruh terhadap kinerja pemeriksa di Inspektorat Kabupaten Bangka, karena dengan adanya kombinasi dari dua variabel yang dimiliki oleh pemeriksa tentunya akan sangat kuat untuk mendorong peningkatan kinerja pemeriksa.Hal ini juga didukung dari hasil penghitungan nilai koefisien determinasi yang semakin meningkat bila dilakukan uji secara simultan atau serempak, dibandingkan dengan nilai koefisien determinasi yang dilakukan secara parsial atau sendiri-sendiri. Artinya bahwa kinerja pemeriksa akan semakin meningkat dengan kombinasi dari dua variabel yang dimiliki oleh pemeriksa.

\section{KESIMPULAN DAN SARAN}




\section{a. Kesimpulan}

Berdasarkan hasil penelitian dan pembahasan mengenai Pengaruh kompetensi dan perilaku kerja terhadap kinerja pemeriksa di Inspektorat Kabupaten Bangka, maka dapat disimpulkan; (1) Terdapat pengaruh variabel kompetensi terhadap kinerja pemeriksa di Inspektorat,kompetensi terdiri dari indikator/faktor sikap, pengetahuan dan kemampuan. Sikap merupakan faktordominan terhadap kompetensi pemeriksa, penyebabnya bukan hanya pengalaman dan pendidikan pemeriksa tetapi juga adanya kewenangan dari lembaga yang menetapkan aturan. (2) Terdapat pengaruh variabel perilaku kerja terhadapkinerjapemeriksa di Inspektorat,perilaku kerja mencakup indikator/faktor keterlibatan kerja, semangat dan kegairahan kerja, daya inisiatif kerja, serta keterikatan terhadap organisasi.Keterlibatan kerja merupakan faktor dominan terhadap perilaku kerjahal ini disebabkan oleh pengalaman (masa kerja) dan pendidikan serta adanya perintah tugas dari pemeriksaan yang telah terstruktur. (3) Terdapat pengaruh variabel kompetensi dan perilaku kerja secara bersama-sama terhadapkinerjapemeriksa di Inspektorat. Jika dibandingkanantara dua variabel bebas dari penelitian ini ternyata variabel kompetensi merupakan variabel dominan yang mempengaruhi kinerja pemeriksa.

Pernyataan ini dilihat dari Hasil Uji Sensitivitas ( Standardized Beta Coefficient) yang dilakukan untuk melihat kepekaan variabel bebas terhadap perubahan yang terjadi pada variabel terikat. Nilai Beta coefficient untuk variabel kompetensi adalah sebesar 0,447, sedangkan variabel perilaku kerja sebesar 0,339 , hal ini menunjukkan bahwa variabel kompetensi yang memiliki nilai tertinggi jika dibandingkan dengan variabel perilaku kerja. Dari angka ini dapat disimpulkan bahwa kompetensi lebih menentukan dalam mempengaruhi kinerja pemeriksa, atau dengan kata lain pengaruh variabel independen yang paling dominan terhadap variabel dependen adalah variabel kompetensi. 


\section{b.Saran}

Dengan segala keterbatasan yang telah diungkapkan dan dari hasil kesimpulan penelitian yang peneliti dapatkan, maka peneliti memberikan saran sebagai berikut :

- Kepada Peneliti/Akademisi; agar penelitian selanjutnya memperluasobjekpenelitian padabeberapa Inspektorat serta menambah variabel independen sehingga diharapkan tingkat generalisasi dari analisis akan lebih akurat.

- Kepada Inspektorat Kabupaten Bangka;

1. Terkait dengan kompetensi;

a) Terhadap sikap;sangat diperlukan adanya pengawasan melekat secaraberjenjang;

b) Terhadap pengetahuan; agar diklat/bimtek lebih diintensifkan khususnya dibidang pengawasan;

c) Terhadap kemampuan; adanya roling pemeriksaan terhadap objek pemeriksaan agar pemeriksa menguasai seluruh objek pemeriksaan.

2.Terkait dengan perilaku kerja;

a) Terhadap semangat dan kegairahan kerja; perlu adanya peningkatan pengawasan.

b) Terhadap daya inisiatif kerja; perlu adanya pelimpahan wewenang dalamhal teknis pemeriksaan.

c) Terhadap keterlibatan kerja; monitoring dan evaluasi secara rutin perlu ditingkatkan.

d) Terhadap keterikatan terhadap organisasi; perlu adanya pemberian apresiasi terhadap pemeriksa yang berprestasi.

- KepadaPemerintahkabupatenBangkadisarankanagar dapat memberi perhatianterhadap manajemen sumber daya manusia khususnya dalam pengelolaan faktor-faktor kompetensi danperilakukerja yang melekat pada individu pegawai, sehingga dapatmengoptimalkanperan mereka dalam mencapai kinerja yang diharapkan.

\section{DAFTAR PUSTAKA}

Armstrong, M. 1994. Performance Management.Yogyakarta: Tugu Publisher. 
Atmadinata, A \&Sinamo, J. 1984.Teologi kerja modern dan Etos kerja. Jakarta:Yakin.

Boyatzis, E. 1982. The Competent Manager A Model for effective performance. New York: John Wiley \&Sons.

Cochran, W .1991. Teknik Penarikan Sampel. Boston: Harvard University.

Dharma, S. 2005. Manajemen kinerja, Falsafah Teori dan Penerapannya. Yogyakarta: Pustaka Pelajar.

Hutapea, P \& Thoha, N (2008). Kompetensi Plus,Teori,Desain,Kasus, dan penerapan untuk $H R$ dan Organisasi yang Dinamis,Jakarta:PT Gramedia Pustaka Utama.

Mangkunegara AP. 2006. Evaluasi Kinerja SDM. Bandung: Refika Aditama.

Miller,L, Rankin,N, and Neathey,F. 2001. Competency Frame Works in UKOrganizations. London: CIPD.

Mulyasa,E. 2003. Kurikulum berbasis kompetensi, konsep, karakteristik dan Implementasi. Bandung: PT.Remaja Rosdakarya.

Robbins, S. 2003. Perilaku Organisasi (terjemahan: Dr.Hadayana Pujaatmaka).Jakarta: Prenhalindo.

Santosa \& Ashari. 2005.Statistik dengan Microsoft Excel dan SPSS. Jakarta:Kota.

Santoso, S. 2002. Latihan SPSS Statistik Parametrik. Jakarta: Elexmedia komputindo.

Spencer, L\& Spencer, S. 1993. Competence at Work Models for Superior Performance 1 ed. NewYork: John Willey \& Sons.

Sofo, F. 1999. Human Resource Development, Perspective, Roles and Practice Choice. NWS. Warriewood: Business and Profisional Publishing.

Siahaan, R. 2007. Pedoman Tatacara Pengawasan Atas Penyelenggaraan pemerintah Daerah (Permendagri No.23 Tahun 2007). Jakarta: CV.Novindo Pustaka Mandiri.

Sinamo, J \& Santoso, A. 2002.Pemimpin kredibel, Pemimpin visioner. Jakarta: Institut Darma Mahardhika.

Sugiyono (2009). Metode Penelitian Bisnis. Bandung: Alfabet.

Tsang \& Chiu (2000). The generic work behavior questionnaire (GWBQ): Assessment of core dimensions of generic work behavior of people with 
severe mental illnesses in vocational rehabilitation, Psychiatric Rehabilitation Journal: volume 28, Number 1/summer 2004 (40-47).

\section{Peraturan Perundang-undangan}

Departemen Dalam Negeri Republik Indonesia (2002). Himpunan Peraturan Perundang-undangan Tentang Pengawasan, Inspektorat Jendral Depdagri

Pemerintah Kabupaten Bangka (2008). Peraturan Daerah Nomor 6 tahun 2008Tentang Organisasi dan Tata kerja Inspektorat, Bappeda dan Lembaga teknis Kabupaten Bangka.

Pemerintah Kabupaten Bangka (2008). Peraturan Bupati Bangka nomor 25 Tahun 2008 tentang Penjabaran Tugas dan Fungsi Inspektorat Kabupaten Bangka

Republik Indonesia (1959). Undang-undang nomor 28 tahun 1959 tentang dasarhukum pembentukan Daerah Tingkat II Bangka.

Republik Indonesia (2007). Peraturan Pemerintah Nomor 41 th 2007 TentangOrganisasi Perangkat Daerah. 